don, for his help with flow calibration. We also thank Professor T J H Clark, Dr P J Rees, and Dr G W McMaster for their support of this project.

\author{
References \\ 1 Wright BM. A miniature Wright peak-flow meter. $\mathrm{Br} M e d \mathcal{F} 1978$;ii: \\ 1627-8. \\ ${ }^{2}$ Hetzel MR, Clark TJH. Comparison of normal and asthmatic circadian \\ rhythms in peak expiratory flow rate. Thorax 1980;35:732-8.
}

${ }^{3}$ Webb J, Clark TJH, Chilvers C. Time course of response to prednisolone in chronic airflow obstruction. Thorax $1981 ; 36: 18-21$.

4 Turner-Warwick M. On observing patterns of airflow obstruction in chronic asthma. Br $\mathcal{F}$ Dis Chest 1977;71:73-86.

5 Bellamy D, Hutchison DCS. The effects of salbutamol aerosol on lung function in patients with pulmonary emphysema. $\mathrm{Br} \mathcal{F}$ Dis Chest 1981; $75: 190-6$.

${ }^{6}$ Gardener RM, Hankinson JL, West BJ. Evaluating commercially available spirometers. Am Rev Respir Dis 1980;121:73-82.

${ }^{7}$ Perks WH, Sopwith T, Brown D, Green M. Should values obtained with a bellows spirometer be converted to BTPS ? Thorax 1981;36:225.

(Accepted 5 May 1982)

\title{
Severe acquired immunodeficiency in European homosexual men
}

\author{
J GERSTOFT, A MALCHOW-MØLLER, I BYGBJERG, E DICKMEISS, C ENK, P HALBERG, \\ S HAAHR, MARIANNE JACOBSEN, K JENSEN, J MEJER, J O NIELSEN, H K THOMSEN, \\ J SØNJDERGAARD, I LORENZEN
}

\begin{abstract}
Four previously healthy Danish homosexual men developed Kaposi's sarcoma or opportunistic infections with fever of unknown origin and lymphadenopathy. One patient died of a Pneumocystis carinii pneumonia. Three patients had defective cell-mediated immunity with absent leucocyte interferon production and decreased proliferative response to mitogens and antigens. $T$ lymphocyte helper subsets and natural killer cell activity were reduced. Unstimulated mononuclear cells produced leucocyte migration inhibitor factor. Two patients were sexual partners and three had never been to the USA, where cases of severe acquired immunodeficiency have been reported. Thus, the syndrome must also be suspected in European homosexual men who present with fever of unknown origin, opportunistic infections, or Kaposi's sarcoma.
\end{abstract}

Hvidovre Hospital, University of Copenhagen, Hvidovre, Denmark J GERSTOFT, MD, senior registrar in rheumatology, department of medicine

A MALCHOW-MØLLER, MD, senior registrar in gastroenterology, department of medicine

E DICKMEISS, MD, senior registrar, department of serology

P HALBERG, MD, associate professor of rheumatology, department of medicine

M JACOBSEN, MD, senior registrar, department of pathology

$\mathrm{K}$ JENSEN, MD, associate professor, department of microbiology

$\mathrm{H}$ K THOMSEN, MD, senior registrar, department of pathology

J SØNDERGAARD, MD, professor, department of dermatology

I LORENZEN, MD, professor of rheumatology, department of medicine

Rigshospitalet, University of Copenhagen, Copenhagen, Denmark I BYGBJERG, MD, senior registrar, department of infectious diseases C ENK, MD, research fellow, laboratory of clinical immunology

J O NIELSEN, MD, senior registrar, department of infectious diseases

Institute of Medical Microbiology, University of Aarhus, Denmark $S$ HAAHR, MD, associate professor

Bispebjerg Hospital, University of Copenhagen, Copenhagen, Denmark

J MEJER, MD, senior registrar, department of serology

\section{Introduction}

During the past eight months an increasing number of cases of Kaposi's sarcoma and opportunistic infections have been reported among previously healthy homosexuals in the United States. ${ }^{1-3}$ The symptoms include persistent fever, weight loss, general lymphadenopathy, and splenomegaly. About half of the patients developed Kaposi's sarcoma, which is rare in the West, except in patients receiving long-term immunosuppressive treatment. ${ }^{45}$ Others contracted opportunistic infections, among which Pneumocystis carinii pneumonia was the most common. Immunological studies showed a severe defect in cellular immunity, ${ }^{6-8}$ which may have been a primary factor leading to secondary opportunistic infections and Kaposi's sarcoma. Cytomegalovirus infections may be of pathogenetic importance, but other factors probably also play a part. ${ }^{9}$ The syndrome has the characteristics of an epidemic in the USA. ${ }^{3}$ All previously reported cases were in patients living in the USA, except one who made regular visits. ${ }^{10}$ We report four Danish cases with all the characteristics of those in the USA, which indicates that the syndrome has spread to Europe. Results of some immunological studies are also presented.

\section{Patients and methods}

The four patients were admitted to Hvidovre Hospital between August 1980 and December 1981. The hospital serves a population of 200000 from the urban part of Copenhagen.

\section{IMMUNOLOGICAL STUDIES}

Mononuclear cells were obtained from heparinised venous blood. Lymphocyte cell markers were identified (a) by the percentage of cells rosetting with untreated sheep red blood cells (E-rosettes) ${ }^{\mathbf{1 1}}$; (b) by the percentage of membrane-bound immunoglobulin-positive cells using fluorescein-conjugated polyvalent rabbit anti-human immunoglobulins $^{12}$ (Dakopatts, Denmark); and (c) the percentage of $T$ lymphocytes (helper/inducer cells) (Leu 3a) and $T$ lymphocytes (cytotoxic/suppressor cells) (Leu 2a) by indirect immunofluorescence using the hybridoma-derived biotin-conjugated anti-Leu $3 \mathrm{a}$ and antiLeu 2a antibodies (Becton-Dickinson, USA) and fluorescein-coupled avidin (Becton-Dickinson, USA). 
Functional tests included responses to phytohaemagglutinin, concanavalin A, pokeweed mitogen, and cytomegalovirus measured by ${ }^{14} \mathrm{C}$-thymidine incorporation. ${ }^{13} 14$ Natural killer cell activity and activity as effector cells in antibody-dependent cellular cytotoxicity in ${ }^{51} \mathrm{Cr}$-release assays were measured. The Molt-4 cell line (kindly provided by Dr Mikael Jondal, Karolinska Institute, Stockholm) were used as target cells in the assay for natural killer cell activity ${ }^{15}$ and IgG-coated DBA-2 mouse mastocytoma cells as target cells in the assay for antibody-dependent cellular cytotoxicity..$^{16}$ Lytic units (one unit representing the number of cells giving a cytotoxicity of $25 \%$ ) were calculated as described by Cerottini and Brunner. ${ }^{17}$ Lytic activity was measured by the number of lytic units $/ 10^{6}$ mononuclear cells. Monocyte function tests, ${ }^{18}$ interferon production studies, ${ }^{14}$ leucocyte migration inhibitory factor tests, ${ }^{19}$ and purine enzyme assays ${ }^{20}$ were performed as described.

Antibodies to cytomegalovirus and Chlamydia trachomatis were determined by complement-fixation tests.

\section{Results}

The clinical data are summarised in table $I$ and the results of the immunological studies in table II. (Data for case 1 in table II were not available.) In cases 2 and 3 immunological investigations were also performed at an earlier stage and gave results which were identical with those given in table II.

\section{Case reports}

Case 1-A 27-year-old homosexual man with a two-month history of fever and weight loss was seen in May 1981. He had previously been well, apart from having secondary syphilis four years earlier, which had been adequately treated. He took amyl and butyl nitrites regularly and had not visited the USA. He had generalised lymphadenopathy, violaceous lesions on the palate, and oral thrush. Ten small violaceous, non-raised lesions were present on the face and upper limbs. Chest $x$-ray films showed no abnormalities. Biopsy of the cutaneous and mucous lesions confirmed Kaposi's sarcoma. Neisseria gonorrhoeae and Candida albicans were cultured from the rectum and pharynx respectively. He was treated with ampicillin and mycostatin and transferred to another hospital for cancer chemotherapy. He died five months later of Pneumocystis carinii pneumonia. At necropsy the lesions of Kaposi's sarcoma were found in the skin, palate, hypopharynx, and paratracheal lymph nodes.

Case 2-A 50-year-old homosexual man was referred in January

TABLE I-Clinical features and laboratory findings in four Danish homosexual men with acquired immunodeficiency

\begin{tabular}{|c|c|c|c|c|}
\hline & Case 1 & Case 2 & Case 3 & Case 4 \\
\hline $\begin{array}{l}\text { Age (years) } \\
\text { Sexual contacts } \\
\text { Drug abuse }\end{array}$ & $\begin{array}{l}27 \\
\text { Case } 3 \\
\text { Nitrites }\end{array}$ & $\begin{array}{l}50 \\
\text { Nitrites }\end{array}$ & $\begin{array}{l}37 \\
\text { Case 1 } \\
\text { Nitrites }\end{array}$ & $\begin{array}{l}31 \\
\text { None }\end{array}$ \\
\hline $\begin{array}{l}\text { Fever, weight loss, anaemia, universal } \\
\text { lymphadenopathy* } \\
\text { Skin/mucosal lesions suggestive of Kaposi's sarcoma } \\
\text { Duration of disease (months) } \\
\text { Hepatitis B surface antigen } \\
\text { Cytomegalovirus titre } \\
\text { Chlamydia trachomatis titre (lymphogranuloma test) } \\
\text { Serological examination for syphilis } \\
\text { Clinical and pathological findings }\end{array}$ & $\begin{array}{l}\text { Present } \\
\text { Present } \\
5 \\
\text { Negative } \\
\text { ND } \\
\text { Negative } \\
\text { Negative } \\
\text { Kaposi's sarcoma,P carinii } \\
\text { pneumonia, oral } \\
\text { candidosis }\end{array}$ & $\begin{array}{l}\text { Present } \\
\text { Absent } \\
12 \\
\text { Negative } \\
1 / 128 \\
\text { Negative } \\
\text { Negative } \\
\text { Kaposi's sarcoma, amoebic } \\
\text { dysentery }\end{array}$ & $\begin{array}{l}\text { Present } \\
\text { Absent } \\
23 \\
\text { Negative } \\
1 / 64 \\
1 / 120 \\
\text { Negative } \\
\text { Clostridium difficile } \text { colitis, } \\
\quad \text { anal ulcers }\end{array}$ & $\begin{array}{l}\text { Present } \\
\text { Absent } \\
12 \\
\text { Negative } \\
1 / 128 \\
\text { Negative } \\
\text { Negative } \\
\text { Oral candidosis }\end{array}$ \\
\hline Present condition & Died & Alive, clinically well & Alive, not improved & Alive, not improved \\
\hline
\end{tabular}

*Soft, non-tender, non-adherent glands measuring up to $2 \times 3 \mathrm{~cm}$. ND $=$ Not determined.

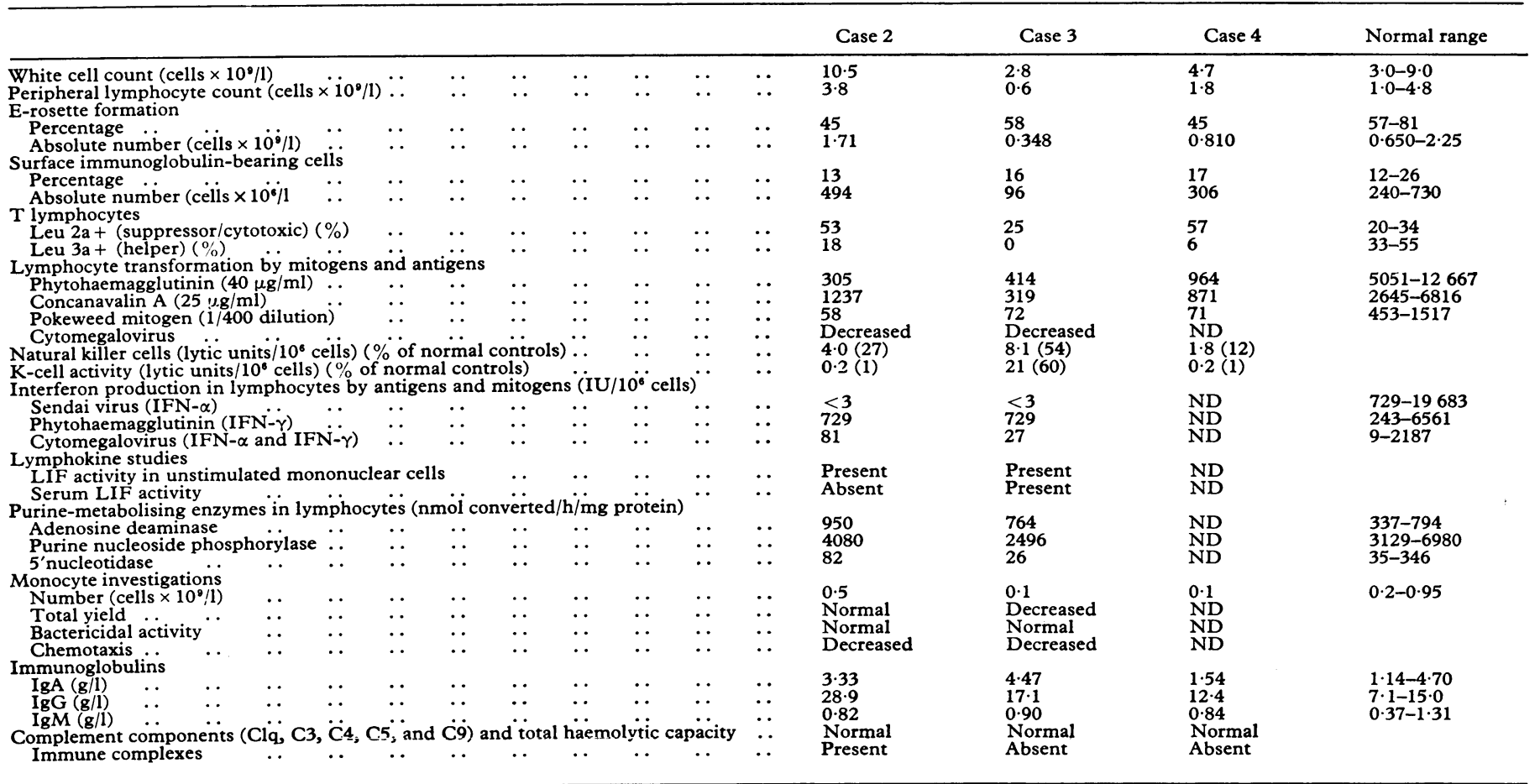

$\mathrm{ND}=$ Not determined $; \mathrm{LIF}=$ Leucocyte migration inhibitory factor . 
1981 because of lymphadenopathy, fever, and weight loss. He had previously been well apart from adequately treated syphilis and gonorrhoea. At the beginning of 1980 he developed chronic diarrhoea. He had been to New York twice early in 1980 and sniffed amyl and butyl nitrites regularly. Physical examination was normal apart from generalised lymphadenopathy. There were no Kaposi's eruptions on the skin or oral mucosa. Radiographic examination of the chest was normal. Rigid sigmoidoscopy showed haemorrhagic proctitis, and Entamoeba histolytica was found in the faeces on two separate occasions. Biopsy of the lymph nodes from the upper limb and inguinal region showed typical evidence of Kaposi's sarcoma. The patient was treated with metronidazole twice. At present he is clinically well and not receiving any chemotherapy; the lymphadenopathy persists.

Case 3-A 37-year-old homosexual man was seen in August 1980 because of persistent fever and arthralgia. He had previously been well apart from adequately treated syphilis and gonorrhoea. The patient in case 1 had been his regular sexual partner. He had never been to the USA but sniffed amyl and butyl nitrites frequently. On physical examination he appeared chronically ill with generalised lymphadenopathy, moderate enlargement of the spleen, and fine rales over both lungs. Chest $x$-ray films showed infiltration of both lungs. Apart from oral candidosis microbiological examination gave negative results to all cultures. Lung biopsy showed alveolitis but no microorganisms were found. The pulmonary symptoms disappeared spontaneously but the fever persisted. In the autumn of 1981 he developed diarrhoea and anal ulcers. Clostridium difficile was cultured twice in the faeces and was treated with oral vancomycin on both occasions. The diarrhoea stopped but the anal ulcers persisted. Attempts to identify a causal organism, including culture for herpes simplex virus, were unsuccessful. A therapeutic trial with the immunostimulant Bestatin (Nippon Kayaku Co, Japan) did not alter his clinical condition or appreciably improve the immunological findings.

Case 4-A 31-year-old homosexual man was referred in December 1981 with lymphadenopathy and fever. He had a 12-month history of fatigue, weight loss, pain on swallowing, and recurrent anal ulcers. He had not been to the USA and denied using nitrites or other drugs. He lived with another homosexual man who had been to the USA and used nitrites regularly. On examination he had generalised lymphadenopathy, splenomegaly, and oral thrush. Histological examination of a lymph node from the axillary region showed nonspecific "reactive alterations." The oral thrush was treated with mycostatin. After one month of observation he still had fever, but microbiological examination gave negative results.

\section{Discussion}

Four previously healthy Danish homosexual men had severe acquired immunodeficiency. In one patient immunological investigations were not performed but the clinical diagnosis of Kaposi's sarcoma and opportunistic infection suggests that he too must have been immune deficient. Three of the cases were the first to be reported in patients who had not previously visited the USA. This indicates that the disease can be acquired outside the USA. All four patients, however, had had sexual contact with homosexual men who had visited or lived in the USA. This is consistent with, but not proof of, an infectious aetiology. Two of the cases (cases 1 and 3) appear to be the first to be reported in patients with known sexual contact. The manifestations of the syndrome were different in these two patients: one developed Kaposi's sarcoma and a fatal Pneumocystis carinii pneumonia; the other had chronic anal ulceration and continuous fever. Thus, immunodeficiency may be the common pathogenetic pathway responsible for the different clinical manifestations in these patients.

The immunological studies showed severe defects in cellular immunity with a reduction of the $\mathrm{T}$ lymphocyte helper subsets, reduced proliferative response, a decreased natural killer cell activity, and impaired monocyte function. These findings agree with and extend other reports. ${ }^{6-8}$ The finding of spontaneous leucocyte migration inhibitory factor production, absent leucocyte interferon production (IFN- $\alpha$ ), and (in one patient) decreased 5'nucleotidase activity is of interest, since this has also been reported in association with decreased cellular immunity in patients with mononucleosis due to the Epstein-Barr virus or cytomegalovirus infection (unpublished observations). ${ }^{21}{ }^{22}$ The aetiology of the immune deficiency is at present unknown. Several reports have suggested that cytomegalovirus may be the causal agent but final proof is lacking. ${ }^{9}$ Amyl and butyl nitrite sniffing have also been suggested ${ }^{23}$; however, one of our patients did not sniff nitrites. Carefully conducted epidemiological investigations may lead to a better understanding of the environmental factors responsible for this new syndrome. The present report draws the attention of European doctors to the syndrome of severe acquired immunodeficiency in homosexual men.

We thank J M Rhodes and J Bennedsen, National Serum Institute, who performed the monocyte studies.

Correspondence and requests for reprints should be addressed to: Dr J Gerstoft, Department of Medicine, Division of Rheumatology, Hvidovre Hospital, Kettegård Allé 30, DK 2650 Copenhagen, Denmark.

\section{References}

${ }^{1}$ Gottlieb MS, Schanker HM, Fan PT, et al. Pneumocystis pneumoniaLos Angeles. Morbidity and Mortality Weekly Report 1981;30:250-2.

${ }^{2}$ Hymes KB, Cheung T, Greene JB, et al. Kaposi's sarcoma in homosexua men-a report of eight cases. Lancet 1981 ;ii:598-600.

3 Auerbach DM, Bennett JV, Brachman PS, et al. Epidemiologic aspects of the current outbreak of Kaposi's sarcoma and opportunistic infections. $N$ Engl f Med $1982 ; 306: 248-52$.

${ }^{4}$ Klepp O, Dahl O, Stenwig JT. Association of Kaposi's sarcoma and prior immunosuppressive therapy: A five-year material of Kaposi's sarcoma in Norway. Cancer 1978;42:2626-30.

${ }^{5}$ Harwood AR, Osoba D, Hofstader SL, et al. Kaposi's sarcoma in recipients of renal transplants. Am $\mathcal{F}$ Med 1979;67:759-65.

${ }^{6}$ Masur H, Michelis MA, Greene JB, et al. An outbreak of communityacquired Pneumocystis carinii pneumonia: Initial manifestation of cellular immune dysfunction. $N$ Engl F Med 1981;305:1431-8.

7 Gottlieb MS, Schorff R, Schanker HM, et al. Pneumocystis carini pneumonia and mucosal candidiasis in previously healthy homosexua men : Evidence of a new acquired cellular immunodeficiency. $N$ Engl $\mathcal{F}$ Med $1981 ; 305: 1425-31$.

${ }^{8}$ Siegal FP, Lopez C, Hammer GS, et al. Severe acquired immunodeficiency in male homosexuals manifested by chronic perianal ulcerative herpes simplex lesions. $N$ Engl f Med $1981 ; 305: 1439-44$.

9 Anonymous. Opportunistic infections and Kaposi's sarcoma in homosexua men. $N$ Engl $\mathcal{F}$ Med $1981 ; 305: 1465-7$.

10 du Bois RM, Branthwaite MA, Mikhail JR, Batten JC. Primary Pneumocystis carinii and cytomegalovirus infections. Lancet $1981 ; \mathrm{ii}: 1339$.

11 Jondal $M$, Holm G, Wigzell $H$. Surface markers on human $T$ and $B$ lymphocytes. 7 Exp Med 1972;136:207-15.

12 Papamichael M, Brown JC, Holborow EJ. Immunoglobulin on the surface of human lymphocytes. Lancet 1971 ;ii :850.

13 Waithe WI, Hirschhorn K. Lymphocyte response to activators. In: Weir DM, ed. Handbook of experimental immunology, vol 2, 3rd ed. Oxford: Blackwell Scientific Publications, 1978.

14 Skovmann-Sörensen O, Schröder H, Möller-Larsen A, Haahr S. Cellular and humoral immunity in Hodgkin's disease. Scand $\mathcal{f}$ Haematol 1981; 27:171-80.

15 Jondal M, Pross H. Surface markers on human B and T lymphocytes. Cytotoxicity against cell lines as a functional marker for lymphocyte subpopulations. Int $\mathcal{F}$ Cancer 1975 ;15:596-605.

${ }^{16}$ Zeijlemaker WP, Roos $M$, Schellekens P, Eijsvogel VP. Antibodydependent human lymphocytotoxicity: A microassay system. Eur $\mathcal{F}$ Immunol 1975;5:579.

17 Cerottini JC, Brunner KT. Cell-mediated cytotoxicity, allograft rejection and tumor immunity. Adv Immunol 1974;18:67.

18 Nielsen H, Bennedsen J, Larsen SO, Rhodes JM, Viskum K. Defective monocyte chemotaxis in pulmonary tuberculosis. European fournal of Tuberculosis 1982 (in press).

19 Bendtzen $\mathrm{K}$. The production of heterologous antibodies to the human lymphokine leucocyte migration inhibitory factor (LIF). Cell Immunol 1977;29:382.

${ }^{20}$ Mejer J, Nygaard P. In: Inborn errors of immunity and phagocytosis. Leicester: MTP Press, 1979:181.

${ }^{21}$ Palit J, Bendtzen K, Andersen V. Production of leucocyte migration inhibitor factor (LIF) in infectious mononucleosis. Clin Exp Immunol $1978 ; 31: 66-71$.

${ }^{22}$ Quagliata F, Faig D, Conklyn M, Siller R. Studies on the lymphocyte 5'nucleotidase in chronic lymphocytic leukemia, infectious mononucleosis, normal subpopulations, and phytohemagglutinin-stimulated cells. Cancer Res 1974;34:3197-202.

${ }^{23}$ Goedert JJ, Neuland CY, Wallan WC, et al. Amyl nitrite may alter Tlymphocytes in homosexual men. Lancet $1982 ; \mathrm{i}: 412-5$.

(Accepted 17 May 1982) 